\title{
Production of a Monoclonal Antibody Selective to Human Transitional Cell Garcinoma
}

\author{
Nobuyoshi Takahashi, Yukihiro Koizumi, Toshiaki \\ Kawaguchi, Kohichi Takahashi, Tadashi Suzuki and \\ Tominisa Funyu \\ Department of Urology, Hirosaki University School of \\ Medicine, Hirosaki 036
}

\begin{abstract}
Takahashi, N., Koizumi, Y., Kawaguchi, T., Takahashi, K., Suzuki, T. and Funyu, T. Production of a Monoclonal Antibody Selective to Human Transitional Cell Carcinoma. Tohoku J. exp. Med., 1987, 151 (2), 213-220 — In order to detect the bladder tumor specific antigens, the monoclonal antibody (MoAb) No. 10 to human transitional cell carcinoma of the bladder (T.C.C.B.) was obtained. Hybridomas were prepared by cell fusion between the mouse myeloma cell line $\times$ $63 \mathrm{Ag} 8.653$ and the spleen cells of $\mathrm{BALB} / \mathrm{c}$ mouse hyperimmune to the bladder cancer cells (grade 2) from a patient, and were cloned. Consequently 12 MoAbproducing clones were obtained for the panel screening by enzymeimmunoassay (EIA) and then 3 MoAbs (No. 10, 11 and 14) were selected for the testing of reactivity to bladder cancer cells from patients including normal epithelia. Finallly No. 10 was selected as the most appropriate MoAb for this study and was determined IgM with kappa-light chains by EIA. monoclonal antibody (MoAb) ; IgM, kappa ; transitional cell carcinoma of the bladder (T.C.C.B.)
\end{abstract}

The MoAb revolution was widely recognized by awarding the 1984 Nobel Prize in Medicine to Köhler and Milstein (1975), and the various techniques for producing MoAbs have been the subject of interest in recent years. As to the MoAbs in urology, the efforts to produce MoAbs preferential to the transitional cell carcinoma of the bladder (T.C.C.B.) cells have involved in a number of laboratories, but unfortunately these attempts have proved unsuccessful except for some (Grossman 1983 ; Fradet et al. 1984 ; Koho et al. 1984; Masuko et al. 1984; Messing et al. 1984 ; Sasaki 1984 ; Baricordi et al. 1985; Ben-Aissa et al. 1985 ; Trejdosiewicz et al. 1985 ; Young et al. 1985).

We have been preparing MoAbs to the T.C.C.B. cells in order to detect the bladder tumor specific antigens. In this report we describe in detail the production of MoAb (No. 10) binding with the T.C.C.B. cells.

Received September 17, 1986 ; accepted for publication January 12, 1987. 


\section{Materials and Methods}

\section{Production of immunizing cells}

The dispersion of tumor into cell suspension was performed as described below. Fresh surgically removed specimens were obtained from the patients with T.C.C.B., grade $2 \mathrm{~T}_{2}$ NoMo. The samples were freed of fat, connecting tissue and remaining necrotic areas, and then extensively washed in phosphate buffered saline free of $\mathrm{Ca}^{2+}, \mathrm{Mg}^{2+}(\mathrm{PBS}(-))$. Separate portions of tumor were finely minced and washed vigorously with 3 changes of PBS $(-)$. After removal of all debris, small fragments of tissue were forced through a stainless steel mesh (\#150) and resuspended in RPMI-1640 medium (Nissui, Tokyo).

The cell suspensions were washed with medium and then sedimented by centrifugation at $1000 \mathrm{rpm}$ for $5 \mathrm{~min}$ three consecutive times. Released cells were adjusted to $1 \times 10^{7}$ cells/ $\mathrm{ml}$ in RPMI-1640 containing 20\% fetal calf serum (FCS, GIBCO, USA), subsequently added with an equal volume of stored frozen medium (RPMI-1640 with 20\% FCS and 20\% dimethyl sulfoxide (DMSO, Wako, Tokyo)) and stored at $-196^{\circ} \mathrm{C}$ in liquid nitrogen until use.

\section{Production of hybridoma}

\section{Immunization}

The cells stored in liquid nitrogen as described above, were thawed and adjusted to 1$3 \times 10^{7}$ cells $/ 0.5 \mathrm{ml}$ in PBS (-) to utilize for immunizing cells. Male BALB/c mice (5-8 weeks old : Nippon Crea, Tokyo) were immunized with those cells two or three times at intervals of $2-3$ weeks.

Subcutaneous injections were performed for the initial immunization, followed by intraperitoneal inoculations for the subsequent immunization.

\section{Cell fusion}

Immunized mice were sacrificed 3 days after the last immunization. Spleen was removed, floated in PBS (-), torn in small pieces, and filtrated through a stainless mesh (\#150). After washings with 4 changes of RPMI-1640 without FCS (RPMI (-)), spleen cells were harvested and fused with the mouse myeloma cell line $\times 63 \mathrm{Ag} 8.653$ cells at a ratio of $10: 1$ as described below ; the cell mixture, after pelleting by centrifugation at 1,100 rpm for $5 \mathrm{~min}$, of $42.5 \%$ (wt/vol) polyethylene glycol (PEG, Wako, Tokyo) in Minimum Essential Medium (MEM, Nissui, Tokyo) with 15\% DMSO. $20.5 \mathrm{ml}$ of RPMI (-) was added dropweise over a period of $6 \mathrm{~min}$, that is, $0.5 \mathrm{ml}, 5 \mathrm{ml}$ and $15 \mathrm{ml}$ of medium, respectively, in $2 \mathrm{~min}$.

Then the cells were centrifuged at $1,100 \mathrm{rpm}$ for $10 \mathrm{~min}$, adjusted to $3-5 \times 10^{6}$ spleen cells $/ \mathrm{ml}$ in RPMI-1640 medium with $10 \%$ FCS and $50 \mu \mathrm{M}$ 2-mercaptoethanol (Wako, Tokyo), and distributed to 96 -well microplates at a concentration of $3-5 \times 10^{5}$ spleen cells/ well in $0.1 \mathrm{ml}$ hybridoma medium at $37^{\circ} \mathrm{C}$ with $5 \% \mathrm{CO}_{2}$ in a humid atmosphere.

After $24 \mathrm{hr}$ of incubation, $0.1 \mathrm{ml}$ of HAT-medium (supplemented with $0.1 \mathrm{mM}$ hypoxanthine, $400 \mathrm{nM}$ aminopterine and $16 \mu \mathrm{M}$ thymidine) was added to each well for selection of hybridomas. Every 2 or 3 days one-half of the medium in each well was replaced with fresh HAT medium until the growth of hybridomas colonies was observed (ca 2 weeks).

\section{Screening of hybridoma supernatants and cloning}

First screened (Enzymeimmunoassay, EIA). After hybridoma colonies 1-2 mm in diameter formed, well- supernatans were harvested and screened for antibody activity to the original immunizing T.C.C.B. cells with Hybri-Clonal ${ }^{\mathrm{TM}}$ EIA kit (Kirkigaard \& Perry, USA), by the method of Kennett (1980).

Target cells $\left(1 \times 10^{5} /\right.$ wells) were first allowed to adsorb on EIA microplate, fixed for 15 min at room temperature with $2.5 \%$ glutaraldehyde in $\mathrm{PBS}(-)$, and then dried at $37^{\circ} \mathrm{C}$ 
overnight. To block non-specific binding of immunogloblins (Ig) $200 \mu \mathrm{l}$ of blocking solution $(0.7 \%$ Bovine Serum Albumine (BSA)) was added to each well. After 5 min of incubation, those fixed cells were sequentially reacted with ; (1) hybridoma supernatants (100 $\mu \mathrm{l} /$ well) (2) horseradish-perxidase (HRPO)-conjugated goat anti-mouse IgG and IgM $\left(50 \mu \mathrm{l} /\right.$ well), at $37^{\circ} \mathrm{C}$ for $1 \mathrm{hr}$, and then $50 \mu \mathrm{l}$ of ABTS substrate solution (2, $2^{\prime}$-azino-di (3-ethyl-benzthiazoline sulfonic acid)) was added to each well. A positive assay was considered one that turned bluish-green in color upon the addition of substrate.

First cloning. BALB/c spleen cells were adjusted, as described above, to $5 \times 10^{6}$ cells/ $\mathrm{ml}$ RPMI-1640 with 10\% FCS and used as feeder cells. To obtain monoclonality, hybridoma colonies exhibiting positive reactions in the 1st screening, were cloned by limiting dilution at concentrations of 5, 1 and 0.5 cells/well in 96-well plates with those spleen cells as feeder cells, and as a result, cells of the wells with one growing colony were selected for further use in 96-well microplates with more than $50 \%$ negative wells.

Second screening and cloning. After the positive clones were expanded in HT-medium (supplemented with $0.1 \mathrm{mM}$ hypoxanthine, and $16 \mu \mathrm{M}$ thymidine), the same manipulations as mentioned above were repeated.

Third screening. To remove the antibodies binding with HLA-antigens, the patient's own lymphocytes $\left(2 \times 10^{6}\right.$ cells/well) were used as target cells instead of the original immunizing cells.

\section{Characterization of MoAbs specificity}

Panel screening

The extent of MoAbs binding to a panel of malignant cells (listed in Table 1) was determined, by an expanded version of the EIA used for screening described above, with 100 $\mu 1$ of well-supernatants and $5 \times 10^{4}$ target cells/well.

TABLE 1. Results of panel screening

\begin{tabular}{|c|c|c|c|c|c|c|c|c|c|c|c|c|c|}
\hline \multirow{2}{*}{ Cell type } & \multirow{2}{*}{ Cell line } & \multicolumn{12}{|c|}{ Mo Abs } \\
\hline & & No. 2 & 4 & 5 & 8 & 10 & 11 & 13 & 14 & 15 & 16 & 17 & 18 \\
\hline \multirow{4}{*}{$\begin{array}{l}\text { Bladder cancer } \\
\text { (T.C.C.) } \\
\text { obtained } \\
\text { from } \\
\text { cystectomy }\end{array}$} & Case 1 (Grade 2 ) & - & + & + & + & + & + & + & + & + & + & - & + \\
\hline & Case 2 (Grade 1 ) & - & + & + & + & + & + & + & + & + & + & - & + \\
\hline & Case 3 (Grade 1) & - & + & + & + & + & + & + & + & + & + & - & + \\
\hline & Case 4 (Grade 2 ) & - & - & - & - & + & + & + & + & + & + & - & + \\
\hline \multirow[t]{2}{*}{ Bladder cancer } & HT-1197 & - & + & + & + & - & - & + & - & - & + & - & + \\
\hline & $\mathrm{H}^{\prime}$ & - & - & - & - & - & - & - & - & - & + & - & + \\
\hline Wilms't & G & + & + & + & + & - & - & + & + & + & + & - & + \\
\hline Prostatic cancer & PC- & + & + & + & + & - & - & + & - & + & + & + & + \\
\hline $\begin{array}{l}\text { Adreno } \\
\text { cance }\end{array}$ & 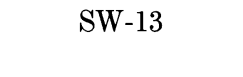 & + & + & + & + & - & - & + & - & + & + & - & + \\
\hline Neurok & & - & - & - & - & - & - & - & - & + & + & - & + \\
\hline Cervix cancer & HeLa & - & - & - & - & - & - & - & - & - & - & - & - \\
\hline Breast cancer & ZR-75-1 & - & - & - & - & - & - & - & - & - & - & - & - \\
\hline Burkitt lymphoma & Daudi & - & - & - & - & - & - & - & - & - & - & - & - \\
\hline
\end{tabular}

Assay was done with the Hybri-Clonal ${ }^{\mathrm{TM}}$ EIA Kit (Kirkigaard \& Perry, USA) and a positive assay $(+)$ was considered one that turned bluish-green in color. 
TABLE 2 Reactivity of MoAbs (No. 10, 11, and 14) with normal bladder epithelia and bladder cancer cells from patients

\begin{tabular}{ccccc}
\hline & $\begin{array}{c}\text { Bladder cancer } \\
\text { Case }\end{array}$ & \multicolumn{4}{c}{ MoAbs.C. } \\
\cline { 3 - 5 } & Grade & No. 10 & 11 & 14 \\
\hline I & 2 & + & + & - \\
II & 2 & + & - & - \\
III & 3 & - & - & - \\
IV & 2 & + & + & + \\
V & 2 & - & - & - \\
VI & 3 & + & + & - \\
VII & 2 & + & - & - \\
VIII & 2 & - & - & - \\
IX & 3 & + & - & - \\
X & 3 & + & - & - \\
XI & Normal & - & - & - \\
XII & bladder & - & - & - \\
XIII & epithelia & - & - & - \\
\hline
\end{tabular}

Assay was done with MoAbs and horseradish peroxidase (HRPO)-labeled goat anti-mouse IgM and $\operatorname{IgG}$, and a positive assay $(+)$ was considered one in which more than 25 percent of the tumor cells were brownish stained around the surface.

Selection of $M o A b$ (No. 10)

The reactivity of the MoAbs selected in the panel screening with normal bladder epithelia and the T.C.C.B. cells (listed in Table 2) was examined using indirect immunoperoxidase staining (IIP); The MoAbs obtained were used for the assays with partial purification with $40 \%$ ammonium sulfate precipitaion. The tissues were fixed in $10 \%$ formalin and routinely processed to prepare paraffinized blocks. From each specimen, serial sections ${ }^{\text {ca }} 3 \mu \mathrm{m}$ in thickness were prepared, on of which was stained with hematoxylin eosin. The sections were deparaffinized with xylene, and were dehydrated by graded alcohl series. After bleaching of endogeneous peroxidase, sections were sequentially reacted with ; (1) $5 \%$ normal goat serum (2) hybridoma supernatants (dilutions of $1: 1$ to $1: 10$ ) (3) horseradish peroxidase (HRPO)-conjugated goat antimouse IgG + IgM (Kirkigaard \& Perry, USA). After thorough washing in PBS, the sections were developed by incubating with DAB (3, $2^{\prime}$-diaminobenzidine) $-\mathrm{H}_{2} \mathrm{O}_{2}$ solution for $10 \mathrm{~min}$, counterstained with methyl greed overnight, washed, dehydrated and coverslipped. In the control experiments, MoAbs were omitted or replaced by the BALB/c mouse serum (dilution of $1: 100$ ).

At the cell level, a positively stained cell was considered one in which a distinct brown hue was visualized around its surface.

Typing of $M o A b$ (No. 10)

The isotype of the MoAb obtained, was determined with Mono Ab-ID EIA kit (Zymed, USA). $50 \mu \mathrm{l}$ of goat anti-murine $\operatorname{IgG}, \operatorname{IgA}$ and $\operatorname{IgM}(10 \mu \mathrm{g} / \mathrm{ml})$ was respectively distribut- 
ed to 96-well microplate, incubated at $4{ }^{\circ} \mathrm{C}$ overnight and attached to wells. After 4 changes of washing with $1 \%$ Tween In PBS, $200 \mu \mathrm{l}$ of the blocking solution $(0.5 \%$ BSA) was added to each well and incubated for $1 \mathrm{hr}$ at $37^{\circ} \mathrm{C}$, followed by $50 \mu \mathrm{l}$ of hybridoma supernatants, rabitt antisera to mouse $\mathrm{Ig}$ (anti- $\mathrm{IgG}_{1}, \mathrm{G}_{2 \mathrm{a}}, \mathrm{G}_{2 \mathrm{~b}}, \mathrm{G}_{3}, \mathrm{~A}, \mathrm{M}$, kappalight chain and lambdalight chain) and horseradish-peroxidase (HRPO)-conjugated goat anti-rabitt IgG. After thorough washings, $100 \mu \mathrm{l}$ of the substrate solution (ABTS. $\mathrm{H}_{2} \mathrm{O}_{2}$ ) was added to each well and incubated for $30 \mathrm{~min}$ at room temperature. Positive wells turned bluish-green in color.

\section{RESULTS}

\section{Preparation of immunizing cells}

The immunizing cells were obtained, as described above, from the fresh surgically removed T.C.C.B. specimens of case 1 (a 58-year-old man) and case 2 (a 70-year-old man), respectively. Each $1 \mathrm{ml}$ of single cell suspensions adjusted to $1 \times 10^{7}$ cells $/ \mathrm{ml}$, was distributed into 200 serum tubes in case 1 and into 100 in case 2 , followed by being stored frozen.

\section{Production of hybridoma}

According to the method as described above, 12 MoAb-producing clones, that is, Nos. 2, 4, 5, 8, 10,11, 13, 14, 15, 16, 17 and 18, as listed in Table 1, were generated from case 2 , in which the patient's lymphocytes were obtained.

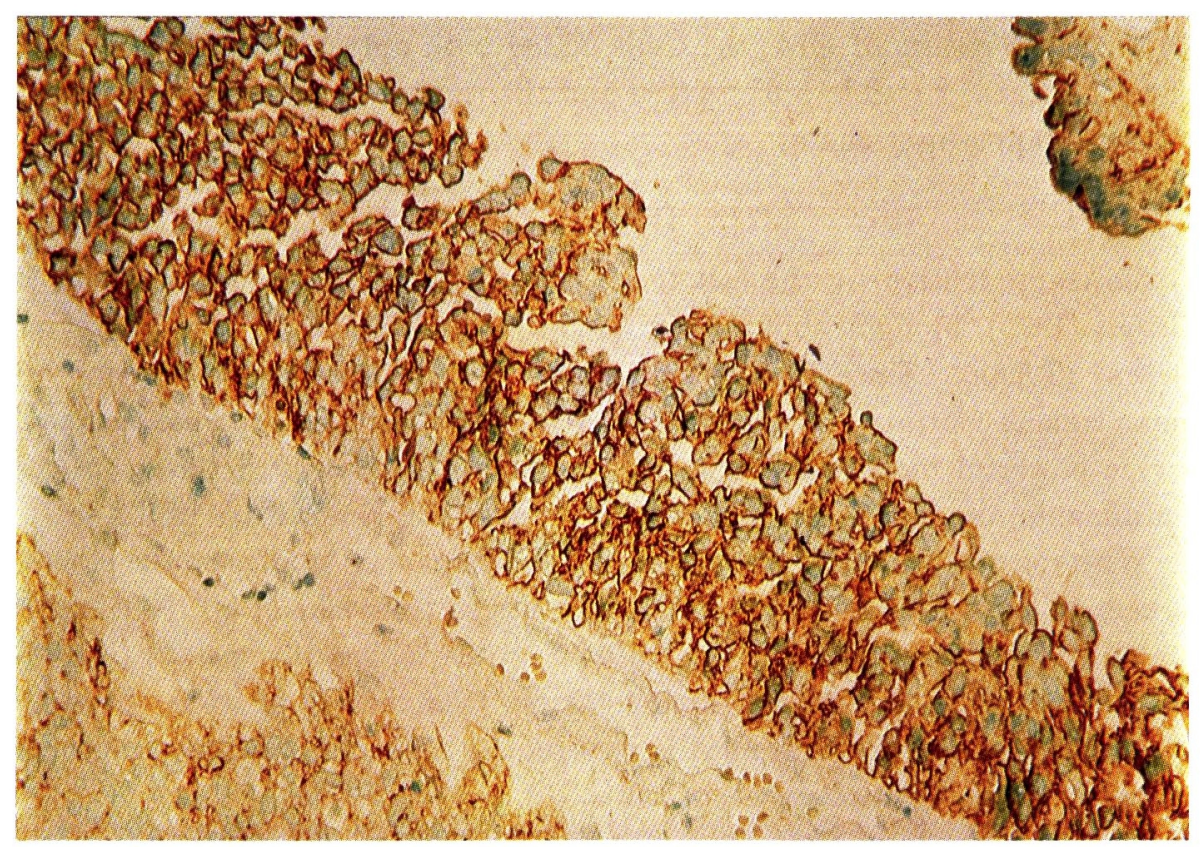

Fig. 1. Indirect immunoperoxidase staining (IIP) of case $\mathrm{X}$ (T.C.C.B., grade 3 ) with MoAb (No. 10) $(\times 70)$. The positivity is localized around the cell membrane with few cytoplasmic staining. 
Characterization of MoAbs specificity

Panel screening

Of the 12 MoAb-producing clones obtained, as shown in Table 1, Nos. 10 and 11 were reactive to all 4 cases of T.C.C.B., but not to human tumor cell lines. No. 14 was the same except for G-401. The other MoAb-producing clones were strongly cross-reactive to most of the tumor cell lines. Consequently $3 \mathrm{MoAb}-$ producing clones (Nos. 10, 11 and 14) were selected and examined moreover.

\section{Selection of MoAb (Nos. 10)}

The reactivity of 3 MoAbs (Nos. 10, 11 and 14) with normal bladder epithelia and the T.C.C.B. cells is shown in Table 2. For each specimen, as visualized in Fig. 1, we considered positive when more than 25 percent of the tumor cells were brownish stained around the surface. The examined cells were 10 cases of T.C.C.B. removed at operation (6 grade 2 and 4 grade 3 ) and 3 of normal bladder epithelia. Of the 3 MoAbs (No. 10, 11 and 14) obtained in the Panel screening, No. 10 was reactive to 7 cases of T.C.C.B. (4 grade 2 and 3 grade 3 ) except for normal bladder epithelia, but No. 11 reacted with only 3 cases of T.C.C.B. (2 grade 2 and 1 grade 3 ). From the above results, No. 10 was identified as the most appropriate MoAb for this study.

Typing of $M o A b$ (No. 10)

From the results of EIA, the wells added with anti-mouse IgM and kappalight chain turned visible bluish-green and the isotype of No. 10 was determined IgM with kappa-light chains.

\section{Discussion}

MoAb-production by the cell fusion techniques established by Köhler and Milstein (1975), brought about a revolution in analysis of the tumor-associated antigens (TAAs). Since then the search for MoAbs specifically reacting with human tumors continues being a field attracting much interest, because MoAbs can provide powerful tools to detect a large number of surface structures (antigenic determinants) on cancer cells and greatly improve our knowledge of TAAs.

With regard to antigenicity of human bladder cancer, studies on the potential markers, such as disappearance of ABH-isoantigen (Newman et al. 1980), appearance of HLA antigen (O'Toole et al. 1982), urothelial specific antigen (Nathrath et al. 1979) and Thomsen-Friedenreich antigen (Summers et al. 1983), have been reported, but the works with MoAbs preferential to human bladder cancer have just taken a step forward in recent years.

We have been preparing MoAbs to the T.C.C.B. cells in order to detect the bladder tumor specific antigens. MoAb (No. 10) was obtained by immunization of $\mathrm{BALB} / \mathrm{c}$ mouse with fresh surgically removed T.C.C.B. cells (grade 2) and subse- 
quent fusion of the spleen cells with the mouse myeloma cell line $\times 63 \mathrm{Ag} 8.653$. The isotype of No. 10 was determined IgM with kappa-light chains.

We refer to a few problems on the technology with particular emphasis on methods to generate MoAbs. The first step in MoAb production is immunization. To avoid the disappearance or modification of the antigenicity on the cultured line, and obtain more preferential MoAb, we used, as immunizing cells, the cells otained from fresh surgically removed bladder cancer. 3 MoAbs analogous to No. 10 have been discussed so far by others: first CD5F, the IgM, which was obtained from the T.C.C.B. cells (grade 3) by Young et al. (1985) ; secondly, GF26.7.3. the IgG2b, which was obtained from the T.C.C.B. cells (grade 3) by Baricordi et al. (1985) ; finally, Om5, which was obtained from lysates of bladder papilloma by Fradet et al. (1984).

The most significant part in MoAb production involves the identification of those clones which secrete antibody of the desired specificity. On this screening process, we adopted the enzyme-linked immunosorbent assay (ELISA or EIA) which was superior in its sensitibity, convenience and promptness. Cloning is also a valuable step to obtain a cloned culture containing identical cells which are producing MoAb. We utilized for this cloning the 3-graded limiting dilution method because of its convenience and popularity.

In addition, to find more relevant, unique MoAbs we carried out the so-called 'Panel screening' by using a panel of malignant cells, and obtained $12 \mathrm{MoAb}$ producing clones. Finally, to select the most preferential MoAb to the T.C.C.B. cells, we examined MoAbs specificity by IIP and obtained the MoAb (No. 10) with the most desired specificity.

To further identify the MoAb (No. 10) specificity from now on, it would be necessary to examine its reactivity with a wider extent of other malignant or normal adult tissues, including fetal tissues and hematopoietic tumors.

\section{References}

1) Baricordi, O.R., Sensi, A., De Vinci, C., Melchiorri, L., Fabris, G., Marchetti, E., Corrado, F., Mattiuz, P.L. \& Pizza, G. (1985) A monoclonal antibody to human transitional cell carcinoma of the bladder cross-reacting with a differentiation antigen of neutrophilic lineage. Int. J. Cancer, 35, 781-786.

2) Ben-Aissa, H., Paulie, S., Koho, H., Biberfeld, P., Hansson, Y., Lundoblad, M.L., Gustafson, H., Jónsdóttir, I. \& Perlmann, P. (1985) Specificities and binding properties of 2 monoclonal antibodies against carcinoma cells of the human urinary bladder. Brit. J. Cancer, 52, 65-72.

3) Fradet, Y., Cordon-Cardo, C., Thomson, T., Daly, M.E., Whitmore, W.F., Jr., Lloyd, K.O., Melamed, M.R. \& Old, L.J. (1984) Cell surface antigens of human bladder cancer defined by mouse monoclonal antibodies. Proc. nat. Acad. Sci. USA, 81, 224228.

4) Grossman, H.B. (1983) Hybridoma antibodies reactive with human bladder carcinoma cell surface antigens. J. Urol. (Baltimore), 130, 610-614.

5) Kennett, R.H. (1980) Enzyme-linked antibody assay with cells attached to polyvinyl chloride plates in monoclonal antibodies Hybridomas. In: A New Dimension in 
Biological Analysis, edited by R.H. Kennett \& T.J. Mckearn, Plenum Press, New York, p. 376 .

6) Köhler, G. \& Milstein, C. (1975) Continuous cultures of fused cells secreting antibody of predefined specificity. Nature (Lond.), 256, 495-497.

7) Koho, H., Paulie, S., Ben-Aissa, H., Jónsdóttir, I., Hansson, Y., Lunblad, M.L. \& Perlmann, P. (1984) Monoclonal antibodies to antigens associated with transitional cell carcinoma of the human urinary bladder. I. Determination of the selectivity of six antibodies by cell ELISA and immnofluorescence. Cancer Immunol. Immunother., 17, 165-172.

8) Masuko, T., Yagita, H. \& Hashimoto, Y. (1984) Monoclonal antibodies against cell surface antigens present on human urinary bladder cancer cells. J . nat. Cancer Inst., 72, 523-530.

9) Messing, E.M., Bubbers, J.E., Whitmore, K.E., deKernion, J.B., Nestor, M.S. \& Fahey, J.L. (1984) Murine hybridoma antibodies against human transitional carcinomaassociated antigens. J. Urol. (Baltimore), 132, 167-172.

10) Nathrath, W.B.J., Detheridge, F. \& Franks, L.M. (1979) Species cross-reacting epithelial and urothelial specific antigens in human fetal, adult and neoplastic bladder epithelium. J. nat. Cancer Inst., 63, 1323-1327.

11) Newman, A.J., Jr., Carlton, C.E. \& Johnson, S. (1980) Cell surface A, B or O (H) blood group antigens as an indicator of malignant potential in stage A bladder carcinoma. J. Urol. (Baltimore), 124, 27-29.

12) O' Toole, C.M., Tiptaft, R.C. \& Stevens, A. (1982) HLA antigen expression on urothelial cells : Detection by antibody-dependent cell-mediated cytotoxicity. Int. J. Cancer, 29, 391-395.

13) Sasaki, M. (1984) Production and characterization of monoclonal antibodies to the established human bladder cancer cell lines. Keio J. Med., 33, 39-56.

14) Summers, J.L., Coon, J.S., Ward, R.M., Falor, W.H., Miller, A.W., III. \& Weinstein, R.S. (1983) Prognosis in carcinoma of the urinary tissue blood group ABH and Thomsen Friedenreich antigen status and karyotype of the initial tumor. Cancer Res., 43, 934-939.

15) Trejdosiewicz, L.K., Southgate, J., Donald, J.A., Masters, J.R.W., Hepburn, P.J. \& Hodges, G.M. (1985) Monoclonal antibodies to human urothelial cell lines and hybrids: Production and characterization. J. Urol. (Baltimore), 133, 533-538.

16) Young, D.A., Prout, G.R., Jr. \& Lin, C.-W. (1985) Production and characterization of mouse monoclonal antibodies to human bladder tumor-associated antigens. Cancer Res., 45, 4439-4446. 